\title{
Black Carbon Concentrations and Diesel Vehicle Emission Factors Derived from Coefficient of Haze Measurements in California: 1967-2003
}

Thomas W. Kirchstetter*, Jeffery Aguiar, Shaheen Tonse, T. Novakov

Environmental Energy Technologies Division, Lawrence Berkeley National Laboratory, Berkeley CA, USA

David Fairley

Bay Area Air Quality Management District, Research and Modeling Division, San Francisco, CA, USA

\begin{abstract}
We have derived ambient black carbon (BC) concentrations and estimated emission factors for on-road diesel vehicles from archived Coefficient of Haze $(\mathrm{COH})$ data that was routinely collected beginning in 1967 at 11 locations in the San Francisco Bay Area. COH values are a measure of the attenuation of light by particles collected on a white filter, and available data indicate they are proportional to $\mathrm{BC}$ concentrations measured using the conventional aethalometer. Monthly averaged BC concentrations are up to five times greater in winter than summer, and, consequently, so is the population's exposure to BC. The seasonal cycle in $\mathrm{BC}$ concentrations is similar for all Bay Area sites, most likely due to area-wide decreased pollutant dispersion during wintertime. A strong weekly cycle is also evident, with weekend concentrations significantly lower than weekday concentrations, consistent with decreased diesel traffic volume on weekends. The weekly cycle suggests that, in the Bay Area, diesel vehicle emissions are the dominant source of $\mathrm{BC}$ aerosol. Despite the continuous increase in diesel fuel consumption in California, annual Bay Area average BC concentrations decreased by a factor of $\sim 3$ from the late 1960 s to the early 2000s. Based on estimated annual BC concentrations, on-road diesel fuel consumption, and recent measurements of on-road diesel vehicle $\mathrm{BC}$ emissions, diesel $\mathrm{BC}$ emission factors decreased by an order of magnitude over the study period. Reductions in the $\mathrm{BC}$ emission factor reflect improved engine technology, emission controls and changes in diesel fuel composition. A new BC monitoring network is needed to continue tracking ambient $\mathrm{BC}$ trends because the network of $\mathrm{COH}$ monitors has recently been retired.
\end{abstract}

Keywords: coefficient of haze, black carbon, aethalometer, particulate matter, diesel vehicle, motor vehicle emissions, air quality, air pollution trends

*Corresponding author email address: twkirchstetter@,lbl.gov and telephone:510.486.5319 


\section{Introduction}

Black carbon (BC), a product of incomplete combustion of carbonaceous fuels, is the main sunlight-absorbing component of atmospheric aerosols. The absorption of sunlight by BC contributes to visibility degradation in polluted atmospheres [Horvath 1993] and to anthropogenic climate forcing [Jacobson 2001, Houghton et al. 2001]. BC also poses a public health concern because it is present in particulate matter that is small enough to deposit in the lungs, which causes asthma and other health problems [Pope and Dockery 2006]. BC has been used as an indicator of exposure to diesel exhaust [e.g., Fruin et al. 2004], which has been classified as a toxic air contaminant [CARB 1998] and a suspected carcinogen [Cal EPA 2005].

Coal and diesel are the primary BC-producing fossil fuels. BC emissions are a function of the combustion technology in addition to the amount and type of consumed fuels. The combustion of BC in the United States and other industrialized countries has changed markedly over time, as discussed in Novakov et al. [2003]. In the past, inefficient coal combustion in the domestic and industrial sectors generated most of the anthropogenic $\mathrm{BC}$ emissions. In the second half of the past century, however, petroleum-based fuels replaced coal as the principal BC source in the United States and in Western Europe.

Presently, diesel engines in the transportation sector are the main sources of BC in urban regions in the United States and elsewhere [Bond et al. 1994], and are thus responsible for much of the environmental impacts of BC. It is clear that diesel fuel consumption has increased in the U.S. over the past 30+ years [Cal BOE 2007]; and over this period air pollution abatement policies have resulted in changes to diesel technology. However, it is difficult to say how changing diesel technology has influenced ambient BC concentrations because most measurements of $\mathrm{BC}$ concentration lack long-term and regional coverage. Vehicle emission factors could be combined with fuel consumption data to estimate the historical contribution of diesel vehicles to atmospheric $\mathrm{BC}$, but published emission factors differ by about a factor of ten [Cooke et al. 1999; Bond et al. 2004; Ito and Penner 2005]. Therefore, significant uncertainty accompanies estimates of ambient concentration trends based on published emission factors and fuel consumption data, indicating the need for additional approaches, as suggested previously [Hansen et al. 2003]. 
In lieu of direct measurements of atmospheric $\mathrm{BC}$ concentrations, a retrospective analysis of BC air pollution must rely on proxy data. Novakov and Hansen [2004] estimated atmospheric BC concentrations from "black smoke" data in the U.K. Cass et al. [1984] estimated BC concentrations from reflectance-based tape sampler measurements in southern California. In this study, we used archived measurements of coefficient of haze $(\mathrm{COH})$ to estimate $\mathrm{BC}$ concentrations. $\mathrm{COH}$ was one of the earliest measures of particulate matter air pollution adopted by regulatory agencies. $\mathrm{COH}$ levels were monitored throughout California beginning in the late 1960s, but most $\mathrm{COH}$ monitors have now been retired.

Like modern measurement of BC made with the aethalometer [Hansen et al. 1984], $\mathrm{COH}$ measurement involved drawing a known volume of air through a white filter and periodically measuring the light (from an incandescent bulb) transmitted through the particle-laden filter to determine the aerosol optical density [Hemeon et al. 1953]. Whereas $\mathrm{BC}$ is reported in units of mass concentration $\left(\mu \mathrm{g} \mathrm{m}^{-3}\right)$, the $\mathrm{COH}$ unit was defined as the amount of aerosol that produced an optical density of 0.01 . $\mathrm{COH}$ values express aerosol concentrations in terms of $\mathrm{COH}$ per 1000 linear feet $(305 \mathrm{~m})$ of sampled air. As the optical density of urban aerosols is largely due to light-absorbing black carbon, especially in the visible and near-infrared wavelengths used to measure $\mathrm{COH}, \mathrm{COH}$ values are highly correlated with BC concentrations simultaneously measured using filter-based optical methods [Cass et al. 1984; Allen et al. 1999].

The present analysis focuses on the San Francisco Bay Area of California. We use $\mathrm{COH}$ measurements in this region to estimate how ambient $\mathrm{BC}$ concentrations have changed during the past four decades. Our analysis first considers the relationship between $\mathrm{COH}$ and $\mathrm{BC}$ and then the trends in $\mathrm{BC}$ concentrations over different time scales - weekly, seasonal and long term. This provides information about predominant $\mathrm{BC}$ emission sources, the population's exposure to combustion-derived particulate matter, and the impact of technology changes on ambient $\mathrm{BC}$ concentrations and emissions. Additionally, we estimate the $30+$ yr trend in on-road diesel vehicle $\mathrm{BC}$ emission factors.

\section{Archived COH Data}

$\mathrm{COH}$ levels recorded at approximately 100 sites throughout California are available 
from the California Air Resources Board [CARB, 2006]. We analyzed archived COH data from 11 sites in the San Francisco air basin over a 37-year period (1967 to 2003). These 11 sites, listed below, reported daily average $\mathrm{COH}$ values on most $(65-96 \%)$ of the days in this period. $\mathrm{COH}$ data from other sites in this air basin with limited coverage during this period (4-34\% of daily averages available) were excluded from the analysis.

The 11 included sites under the jurisdiction of the Bay Area Air Quality Management District (BAAQMD) were Concord (Contra Costa county), Fremont (Alameda county), Livermore (Alameda county), Napa (Napa county), Pittsburg (Contra Costa county), Redwood City (San Mateo county), Richmond (Contra Costa county), San Jose (Santa Clara county), San Rafael (Marin county), Santa Rosa (Sonoma county) and Vallejo (Solano county). A map of the San Francisco air basin is available at the BAAQMD’s website: http://www.baaqmd.gov/dst/jurisdiction.htm.

BAAQMD's air pollution monitoring facilities are sited following EPA guidelines and are intended to reflect major pollutant sources. They are located in urban areas where pollutant concentrations are influenced by emissions from traffic on local streets. None of the sites are immediately adjacent to a freeway, but many are within a mile or two, including those at Livermore, Redwood City, San Jose and San Rafael. Both the Redwood City and San Rafael sites have operated 30+ years and are within a few blocks of Highway 101.

The $\mathrm{COH}$ monitoring procedure was not fundamentally changed over the study period (Yamaichi and Stevenson, personal communication, 2007). The most significant change was a switch from manual to automated data acquisition. Thus, the $\mathrm{COH}$ trends discussed below should not be due to changes in sampling methodology.

\section{Results and Discussion}

3.1 Relationship between $\mathrm{COH}$ and BC. The basis for using $\mathrm{COH}$ data to estimate trends in BC stems from the similarity in the techniques used to measure both species, as noted above. Allen et al. [1999] reported a strong linear relationship between $\mathrm{COH}$ levels and aethalometer BC concentrations in Philadelphia during the summer of 1992: BC ( $\mu \mathrm{g}$ $\left.\mathrm{m}^{-3}\right)=5.66 \cdot \mathrm{COH}-0.26$ with $\mathrm{R}^{2}=0.99$ (where $\mathrm{R}^{2}$ is the linear correlation coefficient). As shown in Fig 1, monthly average $\mathrm{COH}$ and $\mathrm{BC}$ measurements recorded in Fresno, 
California (located south of the San Francisco air basin) during the North American Research Strategy for Tropospheric Ozone study [NARSTO, 2007] from December 1999 to August 2002 yield a similar linear relationship: $\mathrm{BC}\left(\mu \mathrm{g} \mathrm{m}^{-3}\right)=5.13 \cdot \mathrm{COH}+0.57$ with $\mathrm{R}^{2}=$ 0.96 . While additional collocated $\mathrm{COH}$ and $\mathrm{BC}$ measurements would strengthen the relationship, the measurements in Philadelphia and Fresno both indicate that the relationship is linear. In the analysis presented below, the average slope (5.4) was used to estimate $\mathrm{BC}$ from measured $\mathrm{COH}$, and the offset was disregarded because it was in one case slightly positive and in the other slightly negative.

3.2 Weekly BC cycle. BC concentrations in the Bay Area show a weekly cycle, which persisted throughout the 37-year observation period. On average over this period, weekday concentrations were about 1.4 times larger than Sunday concentrations, as illustrated in Fig 2a. Dreher and Harley [1998] reported a marked reduction in diesel fuel use and diesel vehicle traffic volume on Sundays in the San Francisco Bay Area. Based on California Department of Transportation freeway motion sensors, Dreher and Harley reported that Sunday diesel truck travel is only about $25 \%$ of the weekday average. In contrast, light-duty gasoline vehicle travel shows relatively little weekly variation. Lightduty vehicle travel is the same on Saturdays as weekdays and only $10 \%$ less on Sundays [Marr et al., 2002]. Therefore, we attribute the weekly pattern in BC to a reduction in diesel traffic on weekends, particularly on Sundays, and we infer that diesel vehicle emissions are a dominant source of BC emissions in the Bay Area. Several others have reported for California regions similar weekly trends in carbonaceous particulate matter concentrations related to decreased diesel traffic volumes on weekends [Lough et al. 2006; Harley et al. 2005; Chinkin et al. 2003; Motallebi et al. 2003].

The weekly cycle in $\mathrm{BC}$ concentrations is seasonally dependent: it is more pronounced in the summer months when $\mathrm{BC}$ concentrations are lowest than in the winter when $\mathrm{BC}$ concentrations are highest (Fig 2b). For example, in July and August the average weekday BC concentration is 1.8 times higher than it is on Sunday, while in December and January, this ratio decreases to 1.2. This seasonal difference in the weekly cycle is at least partly due to pollutant dispersion, which is discussed in more detail below. In the summertime when pollutants are more effectively dispersed and the build up of pollutants in the air basin is at a minimum, the ambient $\mathrm{BC}$ concentration is more sensitive to the 
weekly cycle in emissions than it is in the wintertime, when the baseline pollution level rises due to reduced dispersion. Reduced pollutant dispersion in the wintertime also results in carryover of the previous day's emissions, as evidenced by the monatomic increase in $\mathrm{BC}$ concentration during weekdays in January and February (Fig 2b).

$\mathrm{BC}$ emissions from residential wood burning in the wintertime might also contribute to the seasonal difference in the weekly $\mathrm{BC}$ cycle if wood burning activity increased on weekends. However, this appears not to be the case. A recent survey found that Bay Area households were no more likely to burn wood on weekends than on weekdays [BAAQMD, 2006].

3.3 Seasonal variations. BC concentrations in the Bay Area show pronounced maxima in winter and minima in summer, and this seasonal trend persisted throughout the 37-year period of observation. This seasonal cycle is illustrated in Figs $3 a$ and $b$.

Wintertime $\mathrm{BC}$ concentrations are up to five times higher than summertime concentrations. The similarity in the seasonal variation throughout the Bay Area is indicated by strong inter-site correlations among concentration time series. Linear correlation coefficients $\left(\mathrm{R}^{2}\right)$ among pairs of Bay Area sites, some separated by as far as $140 \mathrm{~km}$, average 0.74 and are generally between 0.65 and 0.85 (Table 1).

The seasonal cycle in $\mathrm{BC}$ concentrations is most likely due to reduced pollutant dispersion during winter months. Glen et al. [1996] reported lower mean mixing height $(570$ vs. $660 \mathrm{~m})$ and mean wind speed ( 3.7 vs. $\left.6.4 \mathrm{~m} \mathrm{~s}^{-1}\right)$ in winter months than in summer months for the San Francisco area. The inter-site correlations in Table 1 indicate that changes in pollutant dispersion occur synchronously throughout the Bay Area. In contrast to seasonal variation in pollutant dispersion, motor vehicle fuel consumption, including diesel, is essentially constant throughout the year [FHA, 2007].

A similar seasonal trend in carbon particle concentrations was observed by Cass et al. [1984] at seven locations in the Los Angeles area (1958 to mid-1981). They attributed the seasonality in concentration to decreased atmospheric dispersion during the late fall and early winter rather than to temporal changes in the emissions from the principal $\mathrm{BC}$ sources, namely diesel vehicles. Diesel vehicle emissions of $\mathrm{BC}$ were considered to be approximately constant throughout the year, as indicated by fuel consumption data [FHA, 2007]. Likewise, Glen et al. [1996] demonstrated that meteorologically driven dispersion, 
not seasonal variation in emissions, caused the same seasonal trend in carbon monoxide concentrations in several urban locations, including the San Francisco air basin.

While meteorology likely dominates the seasonal trend in Bay Area BC concentrations, we considered that increased residential wood burning in the wintertime [Fairley, 2006] might also be a factor. Schauer and Cass [2000] discuss an extreme wood smoke event in Fresno (located south of the San Francisco Bay Area), which offers an upper bound for the contribution of wood burning to ambient BC concentrations. For that highest wood smoke event, a source apportionment indicated that diesel vehicles and wood burning, respectively, contributed 80 and $20 \%$ of the ambient BC. Thus, the typical BC contribution from wood burning in the wintertime is likely substantially lower than $20 \%$.

Note that the seasonality in $\mathrm{BC}$ concentrations is opposite that of photochemical air pollutants, most notably ozone. In the summertime, increased solar insolation (and thus photochemistry) and higher temperatures lead to peak ozone concentrations. While the population's health risk due to ozone exposure is at maximum in the summertime [Tager et al., 2005 and references therein], its exposure-related risk to (toxic and carcinogenic) diesel emissions, as indicated by increased $\mathrm{BC}$ concentrations, is at a maximum in the wintertime, primarily because of the meteorology of this region.

\subsection{Historical trends in BC concentrations and estimated on-road diesel vehicle}

emission factors. Annual average BC concentrations in the Bay Area over the 1967 to 2003 period are shown in Fig. 4a. Annual diesel fuel consumption by on-road motor vehicles in California is also shown for comparison. Taxable fuel sales are used to measure on-road vehicle fuel consumption [Cal BOE, 2007]. While diesel fuel use, the main source of $\mathrm{BC}$ emissions, increased by a factor of $\sim 6, \mathrm{BC}$ concentrations decreased by a factor of $\sim 3$ over the same period. (The estimated BC concentration in 1967 is likely biased high because $\mathrm{COH}$ data were available only for winter months at many of the active sampling locations that year.) The contrast in the trends in $\mathrm{BC}$ concentration and diesel fuel use is striking, especially beginning in the early 1990s when BC concentrations began markedly decreasing despite sharply rising diesel fuel consumption. This contrast suggests that technology changes to reduce $\mathrm{BC}$ emissions have been successful.

Assuming that diesels have been the only significant BC source in the Bay Area, estimated $\mathrm{BC}$ emission factors - the mass of $\mathrm{BC}$ emitted per mass of diesel consumed - for 
the period 1968 - 2003 decreased by an order of magnitude: from about $13 \mathrm{~g} \mathrm{~kg}^{-1}$ in 1968 to less than $1 \mathrm{~g} \mathrm{~kg}^{-1}$ in 2003, as shown in Fig 4b. We used the ratio of the time series of BC mass concentration to fuel consumption (Fig 4a) to estimate the BC emission factors. These ratios are a relative measure of the diesel $\mathrm{BC}$ emission factors, assuming that ambient concentrations are proportional to BC emissions. The absolute emission factors in each year, $i$, are derived by normalizing to the ratio for 1997 and the BC emission factor of $1.3 \mathrm{~g}$ BC per kg of diesel fuel consumed [Kirchstetter et al. 1999], using the following equation:

$\mathrm{BC}\left(\mathrm{g} \mathrm{kg}^{-1}\right)_{\mathrm{i}}=\left(\frac{\mathrm{BC} \text { concentration }}{\text { Diesel consumption }}\right)_{\mathrm{i}} \bullet\left(\frac{\text { Diesel consumption }}{\text { BC concentration }}\right)_{1997} \bullet 1.3 \mathrm{~g} \mathrm{~kg}^{-1}$

The study of Kirchstetter et al. was chosen because it was conducted in the Bay Area and $\mathrm{BC}$ was measured (whereas most vehicle emission studies have not speciated the particulate mass). Moreover, the measurements were conducted in a roadway tunnel, and, therefore, the observed fleet represented the in-use mix of well-maintained and highemitting vehicles. High-emitting vehicles can have a large influence on fleet-average emissions. Bond et al. [2004] reviewed several studies of emissions from well-maintained and high-emitting vehicles and derived a fleet-average $\mathrm{BC}$ emission factor of $1.5 \mathrm{~g} \mathrm{~kg}^{-1}$ for a 1996 emission inventory compilation, which is similar to the value we use in Eqn 1.

3.5 Uncertainty. Uncertainty in the derived emission factors arises due to the assumption that only diesel vehicles contribute to ambient $\mathrm{BC}$ concentrations. While the weekly cycle in $\mathrm{BC}$ concentration (described above) suggests that diesel vehicles are the dominant $\mathrm{BC}$ emitter, other sources likely contribute non-negligibly. Other BC sources may include a) wood burning, as noted above, b) gasoline engines, c) off-road diesel vehicles, and d) industrial use of coal and diesel. We do not consider electric utilities because $\mathrm{BC}$ emissions from these sources are a small fraction of $\mathrm{BC}$ emissions from motor vehicles and there are no coal-fired power plants in California.

a) As discussed above, we inferred from the study of [Schauer and Cass 2000] that wood burning might contribute a maximum of $20 \%$ of wintertime BC emissions. We also noted that wood burning activity is seasonal; very little occurs in the summertime [Fairley, 
2006]. In order to remove uncertainty related to emissions from this source, we derived BC emission factors using summertime $\mathrm{BC}$ concentrations (i.e., $\mathrm{BC}$ concentrations estimated from July through August $\mathrm{COH}$ data). This revised estimate of $\mathrm{BC}$ emission factors (shown as open triangles in Fig $4 \mathrm{~b}$ ) is very similar to the estimate based on annual BC concentrations. Thus, emissions from wood burning do not significantly affect our derived diesel vehicle $\mathrm{BC}$ emission factors.

b) The relative importance of $\mathrm{BC}$ emissions from gasoline-powered motor vehicles was estimated from published emission factors. While the $\mathrm{BC}$ emission factor from diesel vehicles is approximately 40 times larger than from gasoline vehicles, roughly six times more gasoline than diesel fuel is sold in California [Kirchstetter et al. 1999]. Based on BC emission factors, fuel use, and fuel properties reported in Kirchstetter et al., we estimate that gasoline engines contribute about $14 \%$ of on-road BC emissions, which are not included in our emission factor calculations. The relative importance of $\mathrm{BC}$ emissions from gasoline vehicles may have been greater earlier in the study period if gasoline engines were previously much larger BC emitters.

c) The off-road transport sector consists of off-highway vehicles, farming equipment, rail, and ships. Over the US as a whole it contributes a significant fraction of BC emissions. [Bond et al. 1994]. We do not expect emissions from farming equipment to contribute substantially to the San Francisco Bay Area because the major agricultural areas of California lie downwind of the Bay Area. Consumption of diesel fuel in California from off-highway vehicles, rail and ships has remained relatively constant compared to on-road diesel consumption, as shown in Fig 4a. (Due to data unavailability, off-road consumption in Fig 4a includes off-highway vehicle consumption only after 1983.) Since off-road diesels are subject to fewer regulations than on-road diesels, the present-day $\mathrm{BC}$ emission factor of off-road diesels is likely higher than that of regulated on-road diesels and has likely remained relatively constant compared to that of on-road diesels. Bond et al. summarized available off-road emission factor data and reported central values ranging from 1.2 to $3.6 \mathrm{gBC} \mathrm{kg}^{-1}$. If the statewide fuel trends shown in Fig 4a apply to the Bay Area, then based on these emission factors, off-road diesels contribute appreciably to Bay Area BC concentrations. 
d) While estimates for the United States indicate that BC emissions from industry are presently a small fraction of those from transportation [Bond et al. 2004], coal and diesel fuel consumption data for California indicate that industrial BC emissions may have been more important early in the study period [EIA, 2007]. (By comparison, residential and commercial consumption of diesel and coal has been negligible. Energy consumption in these sectors is primarily from natural gas, which contributes negligible amounts of BC.) Similar to off-road diesel consumption, consumption in the industrial sector has remained approximately constant throughout the study period, as shown in Fig 5.

In summary, in light of potentially significant $\mathrm{BC}$ emissions from other combustion sources in the Bay Area, the emission factors in Fig 4b may overstate the emissions from on-road diesels and their historical decrease. Estimating the magnitude of the uncertainty in emission factors is not possible without additional region-specific fuel consumption data. While it is reasonable to assume that diesel vehicle $\mathrm{BC}$ emissions might have had the most influence on measured $\mathrm{COH}$ concentrations - because monitoring facilities are influenced by local traffic and several were close to freeways - it is probable that the values in Fig 4b are upper bounds of the BC emission factors from on-road diesels.

Uncertainty also arises from our assumption that the diesel fuel consumption trend in the San Francisco Bay Area is the same as the statewide trend. Significant differences between Bay Area and statewide diesel consumption trends would result in either an overor under-stated reduction the derived $\mathrm{BC}$ emission factors.

Last, we note that note our assumption of a constant relationship between $\mathrm{COH}$ and $\mathrm{BC}$ (i.e., a constant conversion factor) introduces some uncertainty. We assumed a constant relationship because the concurrent $\mathrm{COH}$ and $\mathrm{BC}$ data cover a short period of time. If the relationship varied over the study period, the estimated BC concentrations and emission factors would be affected. Note that whereas that the estimated BC concentrations depend on the value of the conversion factor, the emission factors depend only on the trend in the $\mathrm{BC}$ concentrations. Therefore, uncertainty in the magnitude of the conversion factor, assuming it is constant over time, does not add to the uncertainty the derived emission factors.

In general the assumptions discussed above become more tenuous farther back in time and lead to greater uncertainty in the estimated BC emission factors early in early 
study period. Conversely, the estimated BC emission factors late in the study period, and the attribution of the decrease in BC concentrations since 1990 to cleaner diesels, probably carry less uncertainty.

\subsection{Reconciliation of estimated BC emission factors with emission regulations}

and vehicle emission measurements. Three periods are evident in the changing $\mathrm{BC}$ emission factors and ambient concentrations over the 1967 to 2003 period: (i) pre 1975 when a substantial decrease in emission factors and ambient concentrations occurred, (ii) 1975 - 1990, a period with a gradual decrease in emission factors and approximately level ambient BC concentrations, and (iii) post 1990 when emission factors and ambient concentrations again decreased markedly. These three time segments qualitatively correspond to the following major milestones in emission control policy described by Lloyd and Cackette [2001].

The first diesel emission controls were directed to visible smoke reduction by national standards introduced in 1970. Diesel fuel composition, including sulfur content reduction, changed concurrently with smoke controls. These changes roughly correspond to the pre-1975 decreases in ambient BC concentrations and emission factors. Diesel particulate matter emissions, of which BC is the majority, were subsequently controlled mostly through improvements in engine design. On road heavy-duty diesel particulate matter emission standards were first implemented in California in 1973. On-road emissions were reduced as new vehicles replaced older more polluting vehicles. These developments correspond to the more-gradual decreasing trend in BC emission factors between 1975 and 1990.

In addition to engine improvements through fleet turnover, emission controls and fuel changes likely contributed to the sharp decrease in BC concentrations and emission factors after 1990. In the 1990s, many urban transit buses were retrofitted with oxidation catalysts to reduce PM and, consequently, BC emissions. In 1993, California limited the sulfur content in diesel fuel to $500 \mathrm{ppm}$ compared to a pre-regulation average of $2500 \mathrm{ppm}$ and limited aromatic hydrocarbon content to $10 \%$. The data in Fig 4 indicate that BC concentrations and emission factors decreased following the 1993 regulations. Reducing the aromatic fuel content is expected to reduce BC emissions. The reduction in fuel sulfur may also have reduced $\mathrm{BC}$ emissions because high fuel sulfur promotes soot formation. 
Sulfur oxides produced in combustion catalyze the recombination of $\mathrm{O}$ and $\mathrm{OH}$ radicals, reduce the degree of acetylene oxidation and thus enhance the formation of soot precursors; see for example Smith [1981] and references therein. McKenzie et al. [2005] showed that lowering the fuel sulfur content from $500 \mathrm{ppm}$ to $50 \mathrm{ppm}$ greatly reduced emissions of polycyclic aromatic hydrocarbons (PAH) from heavy-duty diesel buses. Although BC emissions were not measured in that study, similar reduction of BC can be expected because PAH and BC are both products of incomplete combustion and are often highly correlated [Westerdahl et al. 2005].

A number of vehicle emission studies corroborate technology-driven emission improvements. Prucz et al. [2001] reported that changing diesel engine technology since the early 1990s markedly reduced particulate matter emissions. Heavy-duty diesel vehicle chassis dynamometer tests indicate that particulate matter emission factors trend downward with engine model year: emission factors from 1995 and newer models were ten times less than emissions from pre 1980 models [CRC, 2003]. The introduction of new technology by way of fleet turnover resulted in measured decreases in on-road diesel particulate matter and BC emissions factors of 48 and 39\%, respectively, between 1997 and 2006 [Ban-Weiss et al. 2007].

3.7 Recommended BC measurements. We restate the need for additional side-byside measurements of $\mathrm{COH}$ and $\mathrm{BC}$ and recommend increased routine monitoring of $\mathrm{BC}$. There are few collocated $\mathrm{COH}$ and $\mathrm{BC}$ measurements and, as noted above, more would strengthen the relationship between $\mathrm{COH}$ and $\mathrm{BC}$ derived in this study. Routine monitoring of $\mathrm{BC}$ is needed to continue tracking ambient concentrations. The $\mathrm{COH}$ monitoring network in California has been retired without replacement.

\section{Acknowledgements}

This work was supported by the California Energy Commission's Public Interest Energy Research program, and the Director, Office of Science, Office of Biological and Environmental Research, U.S. Department of Energy. The NARSTO aethalometer BC data was obtained from the NASA Langley Research Center Atmospheric Science Data Center. We thank Eric Stevenson and Stanley Yamaichi of the BAAQMD for providing helpful 
information about $\mathrm{COH}$ sampling in the Bay Area. We also thank the anonymous peer reviewer for his/her helpful comments. 


\section{References}

Allen, G. A, J. Lawrence, and P. Koutrakis, (1999), Field validation of a semi-continuous method for aerosol black carbon (aethalometer) and temporal patterns of summertime hourly black carbon measurements in southwestern PA, Atmos. Environ. 33, 817823.

ARB (2003), http://www.arb.ca.gov/diesel/diesel.htm

BAAQMD, Bay Area Air Quality Management District (2006), Spare the air tonight study, 2005-2006 winter wood smoke season. Report conducted for BAAQMD by True North Research, Encinitas, California, available online: http://www.sparetheair.org/about/2005-winter-report.pdf.

Bond, T.C., D.G. Street, K.F. Yarber, S.M. Nelson, J._H. Woo, and Z. Klimont, A technology-based global inventory of black and organic carbon emissions from combustion, J. Geophys. Res., 109, D14203, doi: 10/1029/2003JD003697, 2004.

Cal BOE, California Board of Equalization, http://www.boe.ca.gov/annual/statindex0405.htm, Table 25A. Taxable distributions of diesel fuel and alternative fuels, effective March 2007.

Cal EPA, California Environmental Protection Agency, "Chemicals known to the state to cause cancer or reproductive toxicity," http://www.oehha.ca.gov/prop65/prop65_list/files/P65single052005.pdf, Proposition 65 list of chemicals, effective May 2005.

CARB, California Air Resources Board, http://www.arb.ca.gov/aqd/aqded/aqded.htm, California air quality data CD, released in 2006.

CARB, California Air Resources Board, Proposed identification of diesel exhaust as a Toxic Air Contaminant. AppendixIII, PartA, ExposureAssessment. ARB, Sacramento, CA, 1998.

Cass, G.R., M. H. Conklin, J. J. Shah, J. J. Huntzicker, and E. S. Macias, (1984), Elemental carbon concentrations: Estimationof an historical data base, Atmos. Environ., 18, 153-162.

CEC, California Energy Commission (1997) Energy Watch, The CEC's summary of energy trends in California, Volume 16, Data through December 1994. Available online, http://www.energy.ca.gov/reports/energywatch-16/.

Chinkin, LR; Coe, DL; Funk, TH; Hafner, HR; Roberts, PT; Ryan, PA; Lawson, DR. (2003) Weekday versus weekend activity patterns for ozone precursor emissions in California's South Coast Air Basin, J. Air Waste Manage. Assoc., 53, 829-843

Cooke, W. F., C. Liousse, H. Cachier, and J. Feichter (1999), Construction of a $1^{\circ} \times 1^{\circ}$ fossil fuel emission data set for carbonaceous aerosol and implementation in the ECHAM4 model (1999), J. Geophys. Res., 104 (D18), 22,137-22,162.

CRC, Coordinating Research Council (2003) Statistical Analysis of CRC E-55/E-59 Phase 1 Data, Available online, http://www.crcao.com/reports/recentstudies2003/E71CompleteReport030301.pdf

Dreher, D.B.; Harley, R.A. A Fuel-Based Inventory for Heavy-Duty Diesel Truck Emissions. J. Air \& Waste Manag. Assoc., 48, 352-358, 1998.

EIA, Energy Information Administration (2007) State Energy Data 2004: Consumption, 1960-2004, California. Available online, http://www.eia.doe.gov/emeu/states/state.html?q_state_a $=$ ca\&q state=CALIFORNI A. 
Fairley, D., Revised Estimates of Wood Burning in the San Francisco Bay Area, Draft Report for the Bay Area Air Quality Management District, 2006.

FHA, Federal Highway Administration (2007), Monthly motor fuel reported by states, Report series is available online, http://www.fhwa.dot.gov/ohim/mmfr/dec02/index.htm.

Fruin, SA; Winer, AM; Rodes, CE, Black carbon concentrations in California vehicles and estimation of in-vehicle diesel exhaust particulate matter exposures, Atmos. Environ., 38, 4123-4133, 2004.

Glen, WG; Zelenka, MP; Graham, RC. Relating meteorological variables and trends in motor vehicle emissions to monthly urban carbon monoxide concentrations, Atmos. Environ., 30, 4225-4232, 1996.

Hansen, ADA; Rosen, H; Novakov, T. The aethalometer - an instrument for the real-time measurement of optical absorption by aerosol particles, Sci. Tot. Environ., 36, 191196, 1984

Hansen, J.; Bond, T.; Cairns, B.; Gaeggler, H.; Liepert, B.; Novakov, T.; Schichtel, B. (2005) Carbonaceous Aerosols in the Industrial Era. EOS, 85, 241-248.

Harley, RA; Marr, LC; Lehner, JK; Giddings, SN (2005) Changes in motor vehicle emissions on diurnal to decadal timescales and effects on atmospheric composition, Environ. Sci. Technol., 39, 5356-5362.

Horvath, H. Atmospheric light absorption - a review. Atmos. Environ., 27A, 293-317, 1993

Hemeon, W.C.L., G.F. Haines, and H.M. Ide (1953), Determinationof haze and smoke concentrations by filter paper samples, Air Repair 3, 22-28.

Houghton, J. T.; Y. Ding, D. J. Griggs, M. Noguer, P. J. van der Linden, and S. Xiaosu, Climate change 2001: the scientific basis, Cambridge University Press, Cambridge, 2001.

Ito, A., and J. E. Penner (2005), Historical emissions of carbonaceous aerosols from biomass and fossil fuel burning for the period 1870-2000, Global Biogeochem. Cycles, 19, GB2028, doi:10.1029/2004GB002374.

Jacobson, M.Z. Strong radiative heating due to the mixing state of black carbon in atmospheric aerosols. Nature, 409, 695-697, 2001.

Kandlikar, M., and G. Ramachandran, (2000), The causes and consequences of particulate air pollution in urban India: A synthesis of the science, Annu. Rev. Energy Environ., 25, 629-684.

Kirchstetter, T.W., R. A. Harley, N. M. Kreisberg, M. R. Stolzenburg, and S. V. Hering, (1999), On-road measurement of the particle and nitrogen oxide emissions from light- and heavy-duty motor vehicles, Atmos. Environ., 33, 2955-2968.

Lloyd, A.C., and T. A. Cackette (2001), Diesel engines: Environmental impact and control, J. Air \& Waste Manage. Assoc., 51, 809-847

Lough, GC; Schauer, JJ; Lawson, DR. (2006) Day of week trends in carbonaceous aerosol concentration in the urban atmosphere, Atmos. Environ., 40, 4137-4149.

Marr, LC; Black, DR; Harley, RA. (2002). Formation of photochemical air pollution in central California. 1. Development of a revised motor vehicle emission inventory. $J$. Geophys. Res., 107, doi: 10.1029/2001JD000689

McKenzie, C. H., L. Godwin, A. Ayoko, L. Morawska, Z. D. Ristovski, and E. R. Jayaratne, (2005), Effect of fuel composition and engine operating conditions on 
polycyclic aromatic hydrocarbon emissions from a fleet of heavy-duty diesel buses, Atmos. Environ., 39, 7836-7848.

Motallebi, N; Tran, H; Croes, BE; Larsen, LC. (2003) Day-of-week patterns of particulate matter and its chemical components at selected sites in California, J. Air Waste Manage. Assoc., 53, 876-888.

NARSTO, Single wavelength aethalometer data from the EPA supersite in Fresno, California, http://eosweb.larc.nasa.gov/cgibin/searchTool.cgi?Dataset=NARSTO_EPA_SS_FRESNO_EC_PM25_FRACTION, effective 2007.

Novakov, T.; Hansen, JE. (2004) Black carbon emissions in the United Kingdom during the past four decades: an empirical analysis, Atm. Environ., 38, 4155-4163.

Novakov, T., V. Ramanathan, J. E. Hansen, T. W. Kirchstetter, M. Sato, J. E. Sinton, and J. A. Sathaye, (2003), Large historical changes of fossil-fuel black carbon aerosols, Geophys. Res. Letters, 30, NO. 6, 1324, doi:10.1029/2002GL016345.

NJ DEP, New Jersey Department of Environmental Protection, http://www.state.nj.us/dep/airmon/part01.pdf, 2001 air quality report, 2001 particulate summary, effective March 2007.

Pope, CA; Dockery, DW. (2006) Health effects of fine particulate air pollution: lines that connect, J. Air Waste Manage. Assoc., 56, 709-742.

Prucz, JC; Clark, NN; Gautam, M; Lyons, DW (2001), Exhaust emissions from engines of the Detroit Diesel Corporation in transit buses: a decade of trends, Environ. Sci. Tech., 35, 1755-1764.

Schauer, JJ; Cass, GR; Simoneit, BRT (2000) Source apportionment of wintertime gasphase and particle-phase air pollutants using organic compounds as tracers, Environ. Sci. Technol., 34, 1821-1832.

Smith, O. I. (1981), Fundamentals of soot formation in flames withapplication to diesel engine particulate emissions, Prog. Energy Combust. Sci., 7, 275-291.

Tager, IB; Balmes, J; Lurmann, F; Ngo, L; Alcorn, S; Kunzli, N. Chronic exposure to ambient ozone and lung function in young adults, Epidemiology, 16, 751-759, 2006.

Westerdahl, D; Fruin, S; Sax, T; Fine, PM; Sioutas, C. Mobile platform measurements of ultrafine particles and associated pollutant concentrations on freeways and residential streets in Los Angeles, Atmos. Environ., 39, 3597-3620, 2005.

Yamaichi, S;.Stevenson, E. (2007) Personal communication with members of the Technical Services Division of the Bay Area Air Quality Management District. 
Table 1. Regression coefficients $\left(\mathrm{R}^{2}\right)$ among monthly BC concentrations at locations throughout the San Francisco air basin (1967-2003).

\begin{tabular}{|l|c|c|c|c|c|c|c|c|c|c|c|}
\hline & Redwod City & Livermore & Richmond & San Jose & San Rafael & Pittsburg & Fremont & Santa Rosa & N a p a & Vallejo & Concord \\
\hline Redw.Citty & $\mathrm{X}$ & & & & & & & & & \\
\hline Livermore & 0.62 & $\mathrm{X}$ & & & & & & & & \\
\hline Richmond & 0.64 & 0.64 & $\mathrm{X}$ & & & & & & & \\
\hline San Jose & 0.84 & 0.66 & 0.67 & $\mathrm{X}$ & & & & & & & \\
\hline S. Raf. & 0.66 & 0.52 & 0.63 & 0.69 & $\mathrm{X}$ & & & & & & \\
\hline Pittsburg & 0.69 & 0.68 & 0.73 & 0.72 & 0.67 & $\mathrm{X}$ & & & & \\
\hline Fremont & 0.75 & 0.70 & 0.74 & 0.78 & 0.68 & 0.78 & $\mathrm{X}$ & & & \\
\hline S. Rosa & 0.73 & 0.57 & 0.73 & 0.81 & 0.68 & 0.70 & 0.75 & $\mathrm{X}$ & & \\
\hline N a p a & 0.82 & 0.66 & 0.77 & 0.86 & 0.74 & 0.80 & 0.78 & 0.87 & $\mathrm{X}$ & \\
\hline Vallejo & 0.69 & 0.68 & 0.78 & 0.77 & 0.71 & 0.73 & 0.77 & 0.74 & 0.79 & $X$ \\
\hline Concord & 0.84 & 0.73 & 0.80 & 0.89 & 0.77 & 0.81 & 0.81 & 0.85 & 0.86 & 0.85 \\
\hline
\end{tabular}




\section{Figure Captions}

Fig 1. Collocated monthly average BC (aethalometer) and $\mathrm{COH}$ levels in Fresno, CA during the North American Research Strategy for Tropospheric Ozone study [NARSTO 2007]. Also shown is the linear regression line reported by Allen et al. [1999] for measurements in Philadelphia, PA.

Fig 2. Average Bay Area BC concentrations by day of week over the period 1967 to 2003 (a) averaged over the whole year and (b) averaged for each month of the year. The error bars reflect the relative standard deviation over sampling sites in the daily average BC concentration.

Fig 3. (a) Monthly $\mathrm{BC}$ concentrations ( $\mathrm{COH}$ also shown), averaged for 11 locations in the San Francisco Bay area from 1980 to 1990. (b) Annual trend in BC over the period 19672003 at each location. Average monthly concentrations are normalized to June.

Fig 4. (a) Estimated annual average BC concentrations in the San Francisco Bay Area (•) and California on-road $(\Delta)$ and off-road $(\diamond)$ diesel fuel sales (see text for definition of fuel categories). The initial BC concentration shown in Fig 4a is likely biased high as it represents only winter data rather than the average of annual data for 1967. (b) Estimated on-road diesel vehicle BC emission factors based on annual average $(\bullet)$ and summertime average $(\Delta) \mathrm{BC}$ concentrations. The error bars in Fig $4 \mathrm{~b}$ reflect the standard deviation over Bay Area sampling sites in the annual average $\mathrm{BC}$ concentration.

Fig 5. California energy consumption estimates from consumption of distillate in the transportation sector $(\bullet)$ and coal $(\Delta)$ and distillate $(\diamond)$ in the industrial sector [EIA, 2007]. 


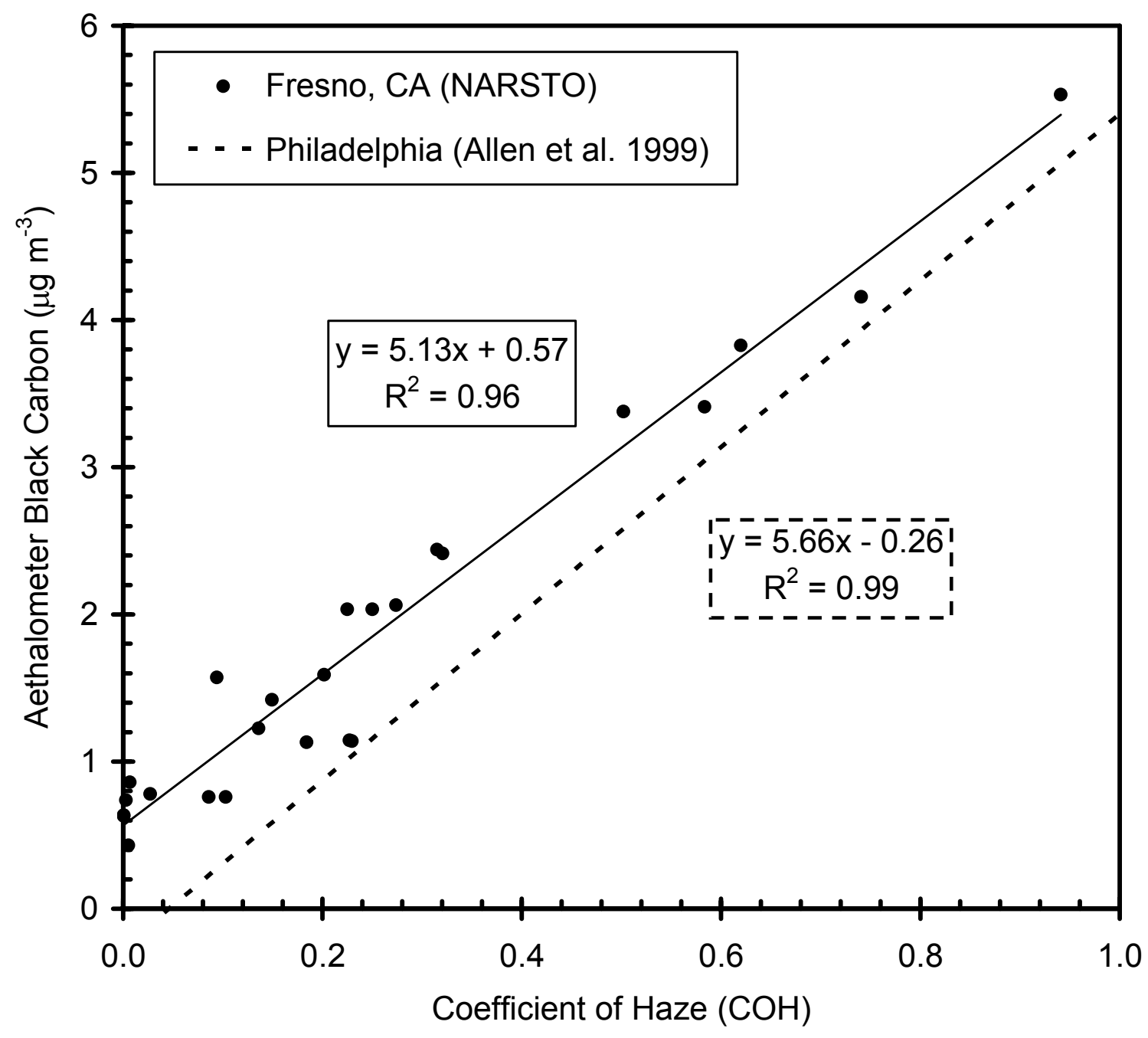

Fig 1. Collocated monthly average BC (aethalometer) and $\mathrm{COH}$ levels in Fresno, CA during the North American Research Strategy for Tropospheric Ozone study [NARSTO 2007]. Also shown is the linear regression line reported by Allen et al. [1999] for measurements in Philadelphia, PA. 
(a)

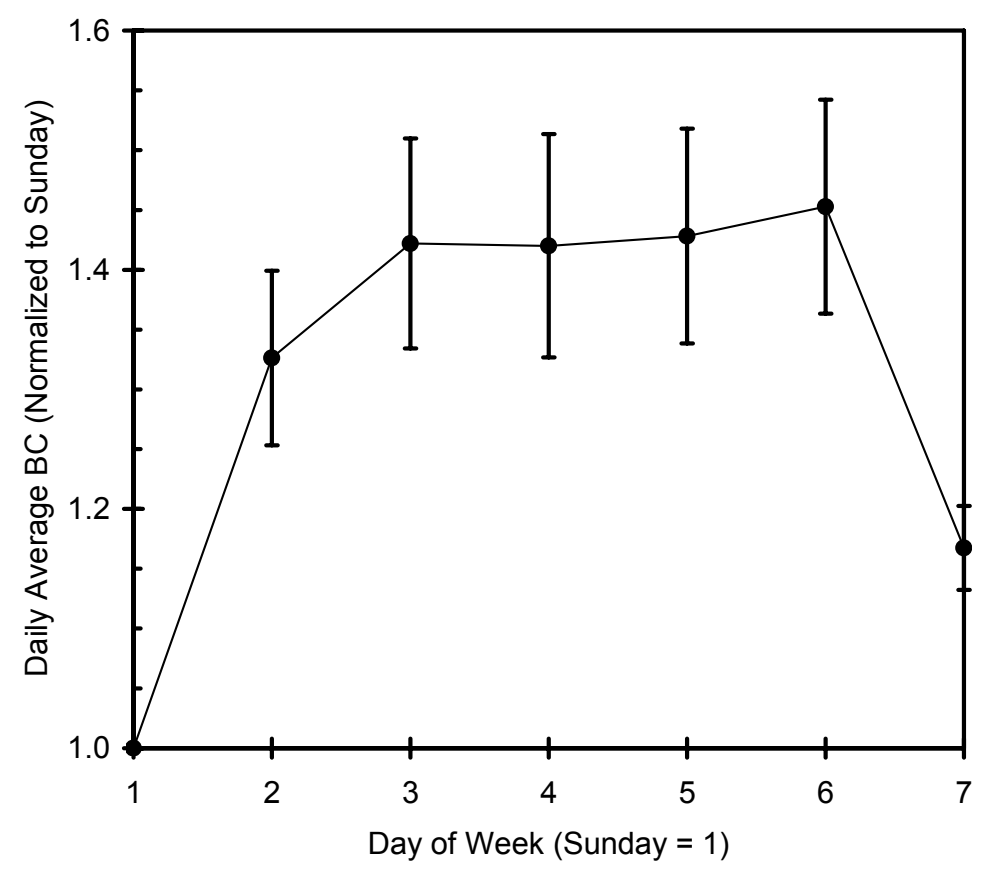

(b)

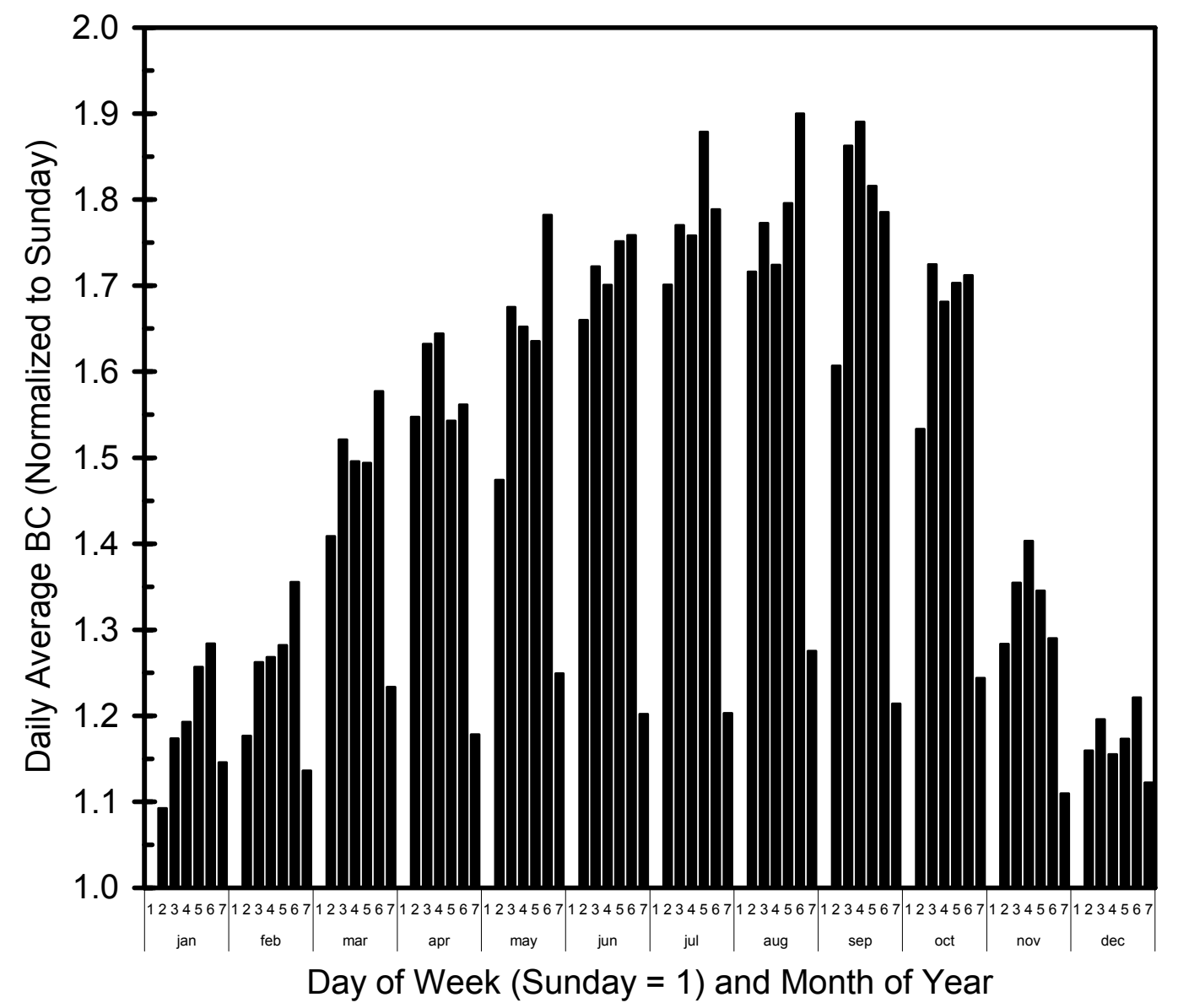

Fig 2. Average Bay Area BC concentrations by day of week over the period 1967 to 2003 (a) averaged over the whole year and (b) averaged for each month of the year. The error bars reflect the relative standard deviation over sampling sites in the daily average $\mathrm{BC}$ concentration. 
(a)

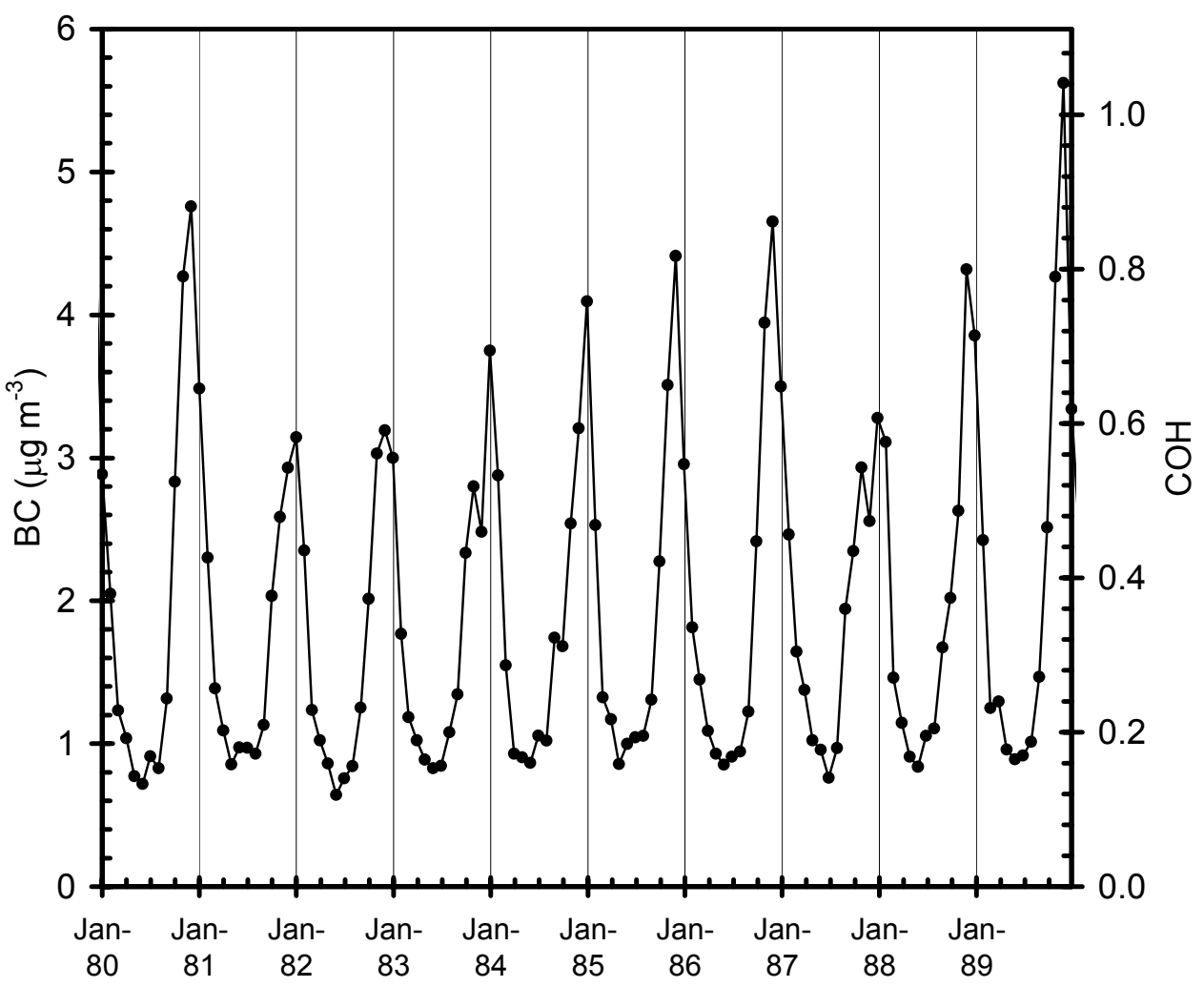

(b)

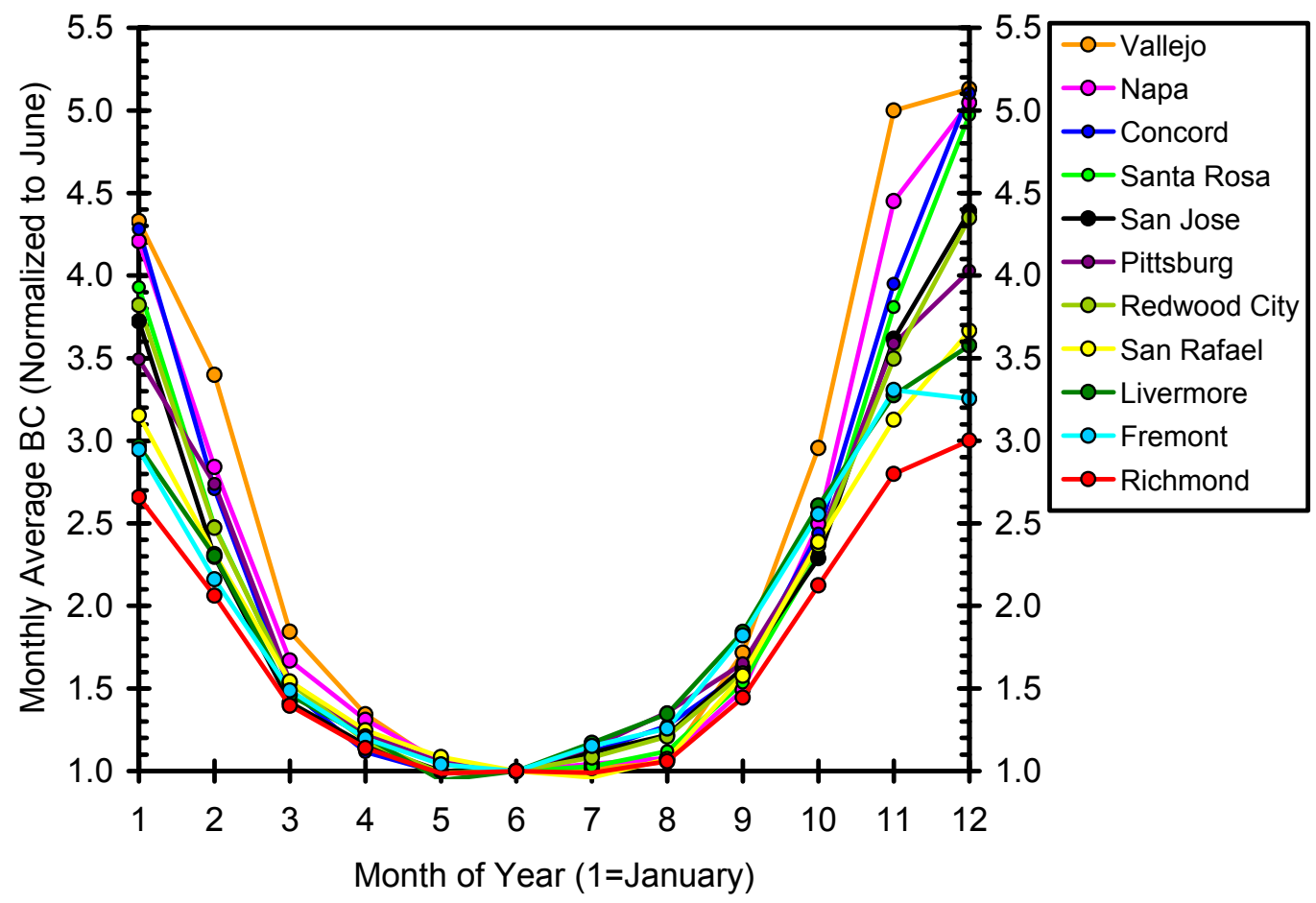

Fig 3. (a) Monthly $\mathrm{BC}$ concentrations ( $\mathrm{COH}$ also shown), averaged for 11 locations in the San Francisco Bay area from 1980 to 1990. (b) Annual trend in BC over the period 19672003 at each location. Average monthly concentrations are normalized to June. 
(a)

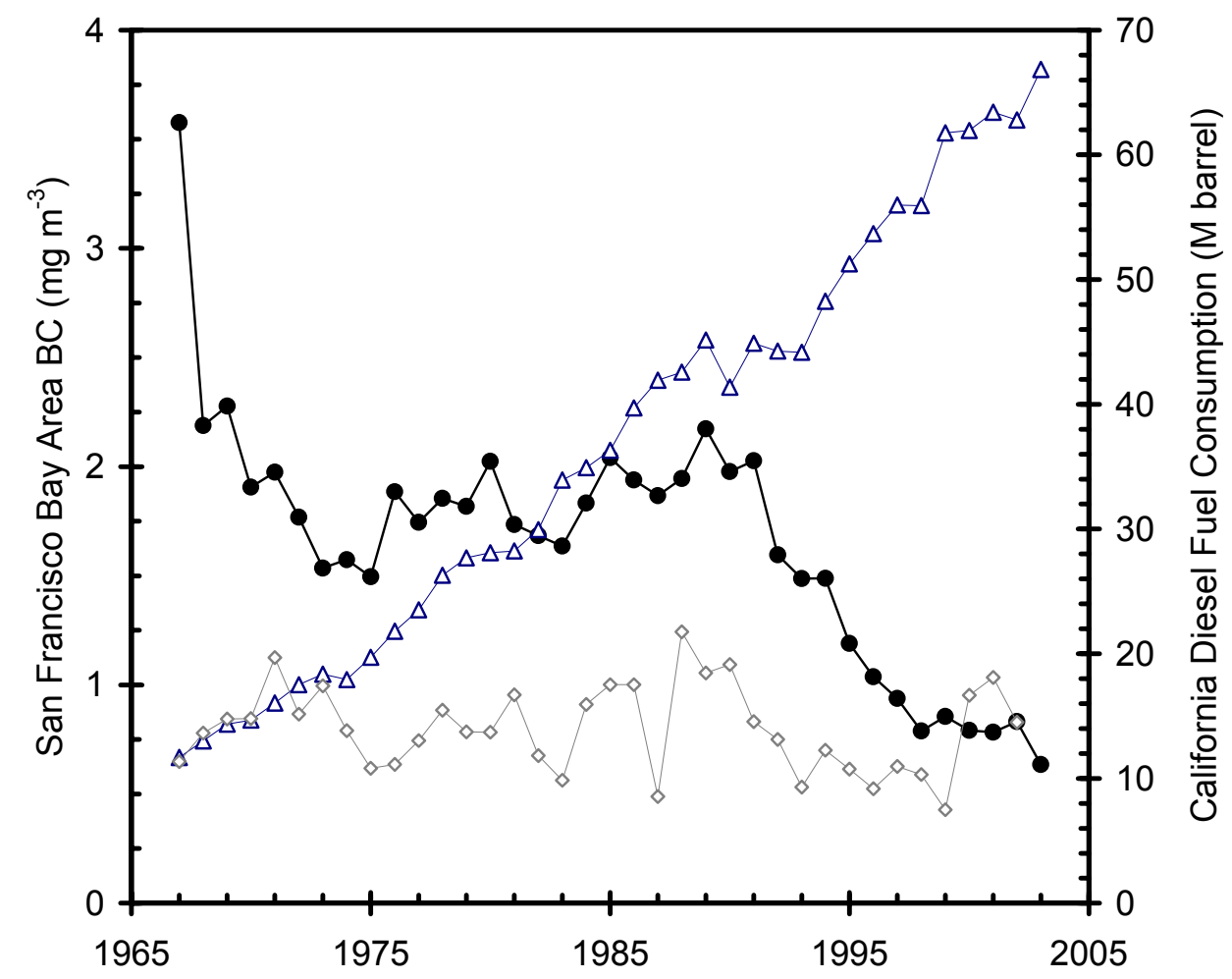

(b)

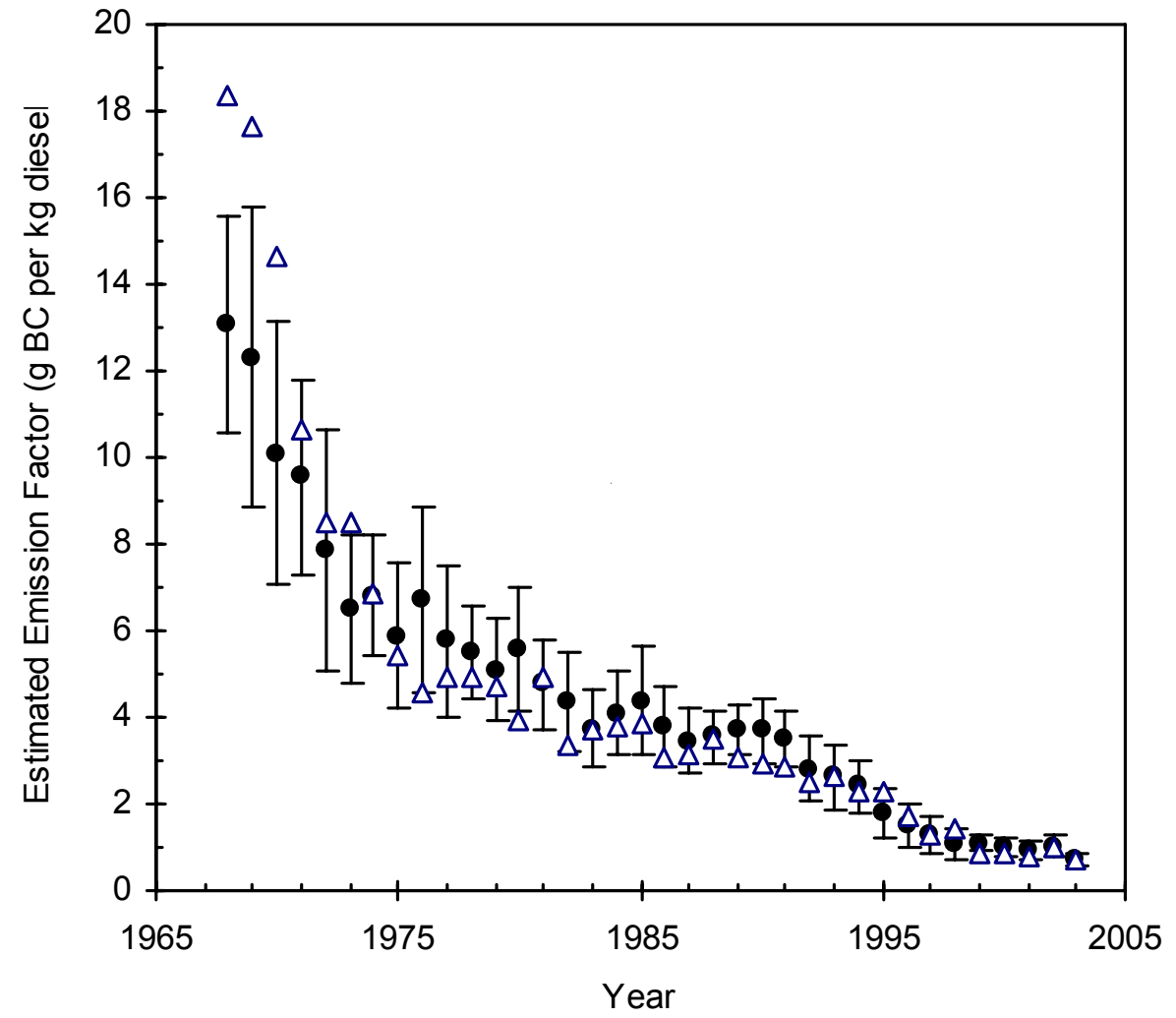

Fig 4. (a) Estimated annual average BC concentrations in the San Francisco Bay Area (•) and California on-road $(\Delta)$ and off-road $(\diamond)$ diesel fuel sales (see text for definition of fuel categories). The initial BC concentration shown in Fig 4a is likely biased high as it represents only winter data rather than the average of annual data for 1967. (b) Estimated on-road diesel vehicle BC emission factors based on annual average $(\bullet)$ and summertime average $(\Delta)$ BC concentrations. The error bars in Fig $4 \mathrm{~b}$ reflect the standard deviation over Bay Area sampling sites in the annual average $\mathrm{BC}$ concentration. 


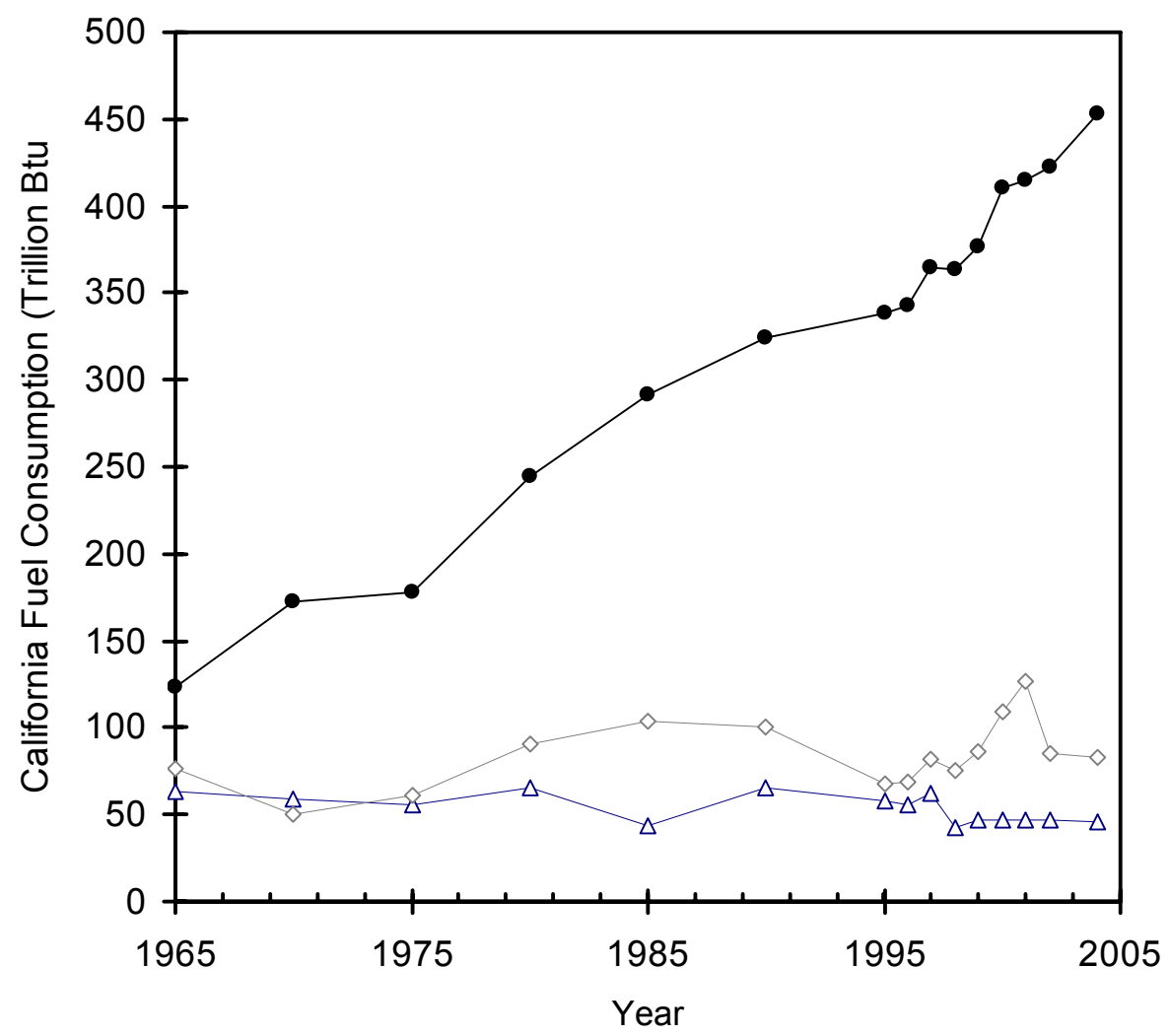

Fig 5. California energy consumption estimates from consumption of distillate in the transportation sector $(\bullet)$ and coal $(\Delta)$ and distillate $(\diamond)$ in the industrial sector [EIA, 2007]. 